\title{
PROCESS AND PROGRESS: REVIEWING THE CRIMINAL JUSTICE ACT
}

\author{
EDWARD C. PRADO*
}

\section{INTRODUCTION}

The Sixth Amendment guarantees the accused in a criminal prosecution the right to assistance of counsel. This right is now understood to mean, in all but petty-offense cases that will not result in imprisonment, that an impecunious accused is entitled to counsel. Further, it is now well established that the government may, after assessing the financial condition of the individual, bear some or all of the cost of representation of those whom it decides to prosecute. Until 1964, however, no authority existed to compensate counsel appointed in the federal courts. With the advent of the Criminal Justice Act of 1964 (the "CJA"), ${ }^{1}$ federal courts could compensate appointed private attorneys, and after the 1970 amendment of the CJA, ${ }^{2}$ courts could establish federal defender organizations to provide representation under the Act. Two decades later, defender organizations were active in more than half of the ninety-four federal judicial districts. They now provide the majority of representations under a mixed system that includes, in each district, representation from a panel of private attorneys in a substantial number of the cases.

In 1990, Congress required a comprehensive study of the federal defender program. The study committee's findings and recommendations are set out in its report to the Judicial Conference of the United States, and will not be recounted in detail here. This article describes the study's approach and methods, both to improve understanding of the program as it now operates and to assist future studies of the program.

\section{BACKGROUND}

The Judicial Improvements Act of 1990 required the Judicial Conference of the United States to conduct a study of the federal appointed counsel program

\footnotetext{
Copyright $\mathcal{O} 1995$ by Law and Contemporary Problems

* U.S. District Judge, Western District of Texas; Chairman of the United States Judicial Conference Committee to Review the Criminal Justice Act (1991-93).

I would like to thank Richard A. Wolff, an attomey who provided counsel and staff support to the Committee, for his generous assistance in connection with the preparation of this article.

1. PUB. L. No. 88-455, 78 Stat. 552 (1964) (codified as amended at 18 U.S.C. $\$ 3006$ A (1988)).

2. Act of Oct. 14, 1970, PUB. L. No. 91-447, 84 Stat. 916 (1970) (codified as amended at 18 U.S.C. \$ 3006A).
} 
under the CJA, as amended, and to submit a report on the results of the study, including proposed changes, to the House and Senate Judiciary Committees. ${ }^{3}$ I recently completed an assignment as chairman of the committee created by the Judicial Conference to perform the study (the "Review Committee"), which culminated in a detailed report to the Conference. ${ }^{4}$ I was deeply honored to be asked by the Chief Justice of the United States to chair the Committee, and I viewed my participation as an opportunity to contribute to improvements in the criminal justice system, with which I have been closely involved throughout my career. ${ }^{5}$ The Judicial Conference considered the Review Committee's report and endorsed many of its recommendations in the report ultimately transmitted to Congress. ${ }^{6}$

The Review Committee faced a plethora of challenging issues. Congress listed a dozen specific areas for scrutiny in its statutory mandate, ${ }^{7}$ many of

3. Judicial Improvements Act of 1990 , Pub. L. No. $101-650, \S 318,104$ Stat. 5116-17 (Dec. 1, 1990).

4. COMmittee to Review the CRiminal Justice ACt, RePORT OF the COMMtTTEe to REVIEW THE CRIMINAL JUSTICE ACT, reprinted in 52 Crim. L. Rep. (BNA) 2265 (1993) [hereinafter COMMITTEE REPORT].

5. Before being confirmed as a federal district judge, I served as U.S. Attorney for the Western District of Texas and as an assistant federal public defender for that district. I also served in state prosecutorial and judicial positions in San Antonio.

6. REPORT OF THE JUDICIAL CONFERENCE OF THE UNITED STATES ON THE FEDERAL DEFENDER PROGRAM (1993), reprinted in 53 Crim. L. Rep. (BNA) 2003 (1993) [hereinafter CONFERENCE REPORT].

7. Congress directed the Judicial Conference, in assessing the effectiveness of the CJA program, to include the following:

(1) The impact of judicial involvement in the selection and compensation of the Federal public defenders and the independence of Federal defender organizations, including the establishment and termination of Federal defender organizations and the Federal public defender and the community defender options.

(2) Equal employment and affirmative action procedures in the various Federal defender programs.

(3) Judicial involvement in the appointment and compensation of panel attorneys and experts.

(4) Adequacy of compensation for legal services provided under the Criminal Justice Act of 1964.

(5) The quality of the Criminal Justice Act of 1964 representation.

(6) The adequacy of administrative support for defender services programs.

(7) Maximum amounts of compensation for attorneys with regard to appeals of habeas corpus proceedings.

(8) Contempt, sanctions, and malpractice representation of panel attorneys.

(9) Appointment of counsel in multidefendant cases.

(10) Early appointment of counsel in general, and prior to the pretrial services interview in particular.

(11) The method and source of payment of the fees and expenses of fact witnesses for defendants with limited funds.

(12) The provisions of services or funds to financially eligible arrested but unconvicted persons for noncustodial transportation and subsistence expenses, including food and lodging, both prior to and during judicial proceedings.

Pub. L. No. 101-650, § 318(b)(1)-(12), 104 Stat. 5116 (1990).

These issues, and the study itself, had been recommended by the Federal Courts Study Committee (the "FCSC"), which was created by act of Congress in 1988 to make an extensive review of the operation of the federal judiciary. See REPORT OF THE FEDERAL COURTS STUDY COMMITTEE 157-58 (1990) [hereinafter FCSC REPORT]; see also id. at 31. 
which were predictably controversial. For example, Congress required that the study examine "judicial involvement" in key areas, ${ }^{8}$ thereby subjecting the judiciary's historic role in CJA administration to comprehensive review. In addition to the areas of study required by statute, the Judicial Conference's standing Committee on Defender Services responded to recommendations by the federal public and community defenders by proposing a supplemental list of issues. ${ }^{9}$ The Review Committee itself identified further issues. Given the ambitious scale of the study, ${ }^{10}$ and the limited time available for its completion, the Review Committee recognized at the outset the magnitude of its endeavor. It also recognized the certainty that its report would draw criticism.

Analyzing the national CJA program, which involved more than 80,000 appointments of counsel and $\$ 200$ million in expenditures in fiscal year 1992 alone, was indeed a challenge. As we finished our task, there was general agreement that the program should be reexamined periodically to ensure appropriate oversight. ${ }^{11}$ The Judicial Conference adopted the Review Committee's recommendation that such a review be undertaken every seven years. Some lessons from the just-completed study will assist current management of the program and provide a springboard for the next intensive review in the year 2000. To this end, I next provide a general chronology of our study.

III

\section{The Committee to Review the Criminal Justice ACT}

A study will inevitably be affected by its design, its available resources, and the time available to complete it. In 1967, the Judicial Conference and the Department of Justice, joint sponsors of the first CJA review, gave Professor Dallin Oaks sole responsibility for performing the analysis. In 1990, at the suggestion of the Federal Courts Study Committee, the Judicial Conference

8. Two general areas for study identified in the statute were the judiciary's role vis-à-vis the "independence" of federal defender organizations and payment of panel attorneys and experts. See supra note 7.

The FCSC had already recommended that the CJA be amended to require that federal defenders be selected by an independent board or commission in each jurisdiction, "rather than by judges before whom they may appear as counsel." FCSC REPORT, supra note 7, at 157-58.

9. See COMMTTEE REPORT, supra note 4, at 2316 endnote $\mathrm{m}$.

10. A small sample of questions included: What can be done both to contain costs and to secure adequate funding to provide constitutionally required defense services now costing hundreds of millions of dollars annually? How should compensation for private CJA panel attorneys be determined? How can the quality of representation be assured?

11. One of the most significant aspects of the study is that it occurred at all. The only other comprehensive study of the CJA's operation took place in its relatively newborn state. Professor Dallin Oaks of the University of Chicago Law School evaluated the CJA in 1967, less than three years after it took effect. See Dallin OAKS, THE CRIMINAL JusticE ACT IN THE FEDERAL DisTRICT COURTS (1967), reprinted in SENATE COMMITTEE ON THE JUDICIARY, 90TH CONG., 2D SESS. (1969) [hereinafter OAKS REPORT]. 
elected to form a committee, ultimately consisting of nine members including its chair, for the same purpose. ${ }^{12}$

Both the individual and the collective approaches have their advantages. While Professor Oaks had the benefit of assistance, he followed his own judgments without compromise. ${ }^{13}$ In contrast, the Review Committee benefitted from the collective experience and views of its members and from the discipline required to achieve consensus. Indeed, I viewed my role as comparable to that of an appellate panel's presiding judge, who ensures that deliberations move forward, but whose views carry no greater weight than those of any other panel member. The Committee operated in this collegial manner throughout its study, and no member or group of members dominated the decisional process. Progress was sometimes slower than desired as the Committee's diverse membership debated the issues. The result, however, was a rigorous examination of the CJA program and thoughtful consideration of recommendations to improve it.

The Review Committee enjoyed extraordinary diversity in its membership. $^{14}$ While all nine members were lawyers, they brought richly varied experience to the task. The Committee included federal judges, law professors, present and former federal and state defenders, private attorneys familiar with federal and state criminal practice, and former prosecutors. ${ }^{15}$ Geographically,

12. The FCSC stated:

In view of the great importance of [the CJA] program, we suggest that the Judicial Conference appoint a special committee to conduct a detailed study of the federal defender program. ... In addition to present and former federal defenders, the study committee should include representatives of the criminal defense bar recommended by the National Legal Aid and Defense [sic] Association, the National Association of Criminal Defense Lawyers, and the Criminal Justice Section of the American Bar Association. Because issues of administration, ethics, and the public trust and interest are involved, participants sensitive to such perspectives should likewise be appointed.

FCSC REPORT, supra note 7, at 158.

13. As Professor Oaks explained:

Although the individuals who have participated in gathering data for this study have given valuable suggestions on an earlier draft, and in fact concur in most of the opinions, conclusions, and recommendations in this report, there has been no effort to achieve consensus on any questions. The content of this final report and the opinions and recommendations which it contains (as well as any errors) are the sole responsibility of the director of the study.

OAKS REPORT, supra note 11, at 7.

14. More complete biographical information on the Review Committee's members is provided in the Committee's report. COMMTTEE REPORT, supra note 4, at 2268-69.

15. The late George H. Revercomb, U.S. District Judge for the District of Columbia, and I were the Article III judges on the Review Committee. Both of us had been serving on the Judicial Conference's standing Committee on Defender Services, which oversees the CJA program. One other member of the Review Committee had extensive judicial experience: Robinson O. Everett, the special editor of this symposium and professor of law at Duke University, is a former chief judge of the U.S. Court of Military Appeals (now the U.S. Court of Appeals for the Armed Forces).

Michael J. Davis is also a law professor, having served on the faculty of the University of Kansas School of Law since 1971, nine years as its dean.

Edward S. G. Dennis, Jr., was U.S. Attorney for the Eastern District of Pennsylvania and Assistant Attorney General of the Justice Department's Criminal Division before joining a Philadelphia law firm. He also served as a member of the FCSC. 
eight of the twelve federal circuits were home to Committee members. There also was racial, ethnic, and gender diversity.

The varying perspectives of Review Committee members had a synergistic effect on deliberations, leaving no assumptions unchallenged. In many areas, there was universal recognition of concerns and unanimous agreement on proposed remedies: enhanced training for appointed counsel, faster processing and payment of CJA vouchers, and clearly defined management standards for federal defender offices, to name only a few. In other areas, where consensus was not so easily achieved, the broad range of experience within the Committee ensured that all points of view were considered. For example, evaluating the effectiveness of CJA administration, which is now solely a judicial responsibility, was enhanced by the Committee's mix of judge and nonjudge members. ${ }^{16} \mathrm{Had}$ the Committee been a traditional Judicial Conference committee composed only of judges, its perspective would have been different. The Committee's diversity in viewpoints was one of its great strengths. This diversity ensured that vital issues were identified, rigorously examined and debated, and reduced to specific recommendations and explained for policymakers.

\section{IV}

\section{INFORMATION GATHERING}

The Review Committee was selected in August 1991 by Chief Justice Rehnquist and first met as an entity the following month. Although there were a number of start-up matters, ${ }^{17}$ the focus of the organizational meeting was to establish a work plan. The Committee was particularly concerned about the Judicial Improvements Act's March 31, 1992 deadline for the Judicial Conference to render its report to Congress. Six months' time was universally deemed insufficient to evaluate the CJA program thoroughly and deliver an assessment to the Judicial Conference, and for the Conference to consider the

The four other members of the Review Committee have extensive criminal defense backgrounds. Judy Clarke, Robert Altman, and Thomas W. Hillier II are present or former federal defenders; Ms. Clarke and Mr. Altman have been directors of community defender organizations; Mr. Hillier is a federal public defender. Mr. Altman is now in private practice and has been a CJA panel attorney. J. Vincent Aprile II has worked for the Kentucky Department of Public Advocacy for 20 years, serving as its general counsel for the past decade. He also was a member of the FCSC.

16. As previously observed, the FCSC, itself consisting of both judges and nonjudges, identified the issue of "judicial involvement" in the appointed counsel program as a matter of concern. FCSC REPORT, supra note 7, at 159 ; see also supra note 8.

17. Even before this initial meeting, I met with various officials of the Administrative Office of the U.S. Courts (the "AO") to discuss the CJA study. The AO provides administrative support for the Judicial Conference and its committees. The chief of the AO's Defender Services Division was detailed to assist the Review Committee as its staff director and counsel. A budget was established for the study, and the staff director was authorized to hire two attorneys and a program assistant. The Committee also retained a reporter. 
issues and submit its report to Congress. Fortunately, Congress concurred in that assessment and extended the due date by one year. ${ }^{18}$

Even with the extension, the Review Committee quickly recognized that the time available to conduct at least a preliminary review was extremely limited. The Committee considered it essential that the Judicial Conference's Committee on Defender Services, the federal defender community, and the general public have an opportunity to critique the Committee's preliminary recommendations before they were submitted to the Judicial Conference. To achieve this goal, the Committee determined to arrive at some tentative conclusions by May 1992. The Committee decided that preparing a draft interim report before the June 1992 meeting of the Committee on Defender Services and submitting it to the September 1992 meeting of the Judicial Conference would best inform those bodies and the public of the Committee's preliminary ideas and generate responses to those ideas.

The Review Committee scheduled its activities to maximize opportunities for communication with all interested parties. It held its second meeting in November 1991 to coincide with a training program for assistant federal defenders, thereby affording an opportunity to exchange ideas with the attending defenders and assistants. ${ }^{19}$ Similarly, the Committee held its third meeting in January 1992 to coincide with the annual conference of federal defenders and the semiannual meeting of the Committee on Defender Services.

In the initial phase of its project, the Review Committee ascertained what work had already been done toward examining the CJA and solicited as many comments as possible on the study topics. This process involved some obvious tasks, but also introduced the Committee to some of the difficulties it would encounter in collecting pertinent information. The straightforward items included compiling a bibliography of source material, examining both the Oaks Report and the seminal 1963 Report of the Attorney General's Committee on Poverty and the Administration of Criminal Justice, ${ }^{20}$ and disseminating requests for relevant information and views from all interested persons and organizations. ${ }^{21}$ The Committee also obtained a "white paper" on state and local appointed counsel programs from a consultant with expertise in state defender systems. ${ }^{22}$

Over the course of the study, it became increasingly evident to the Review Committee that there were deficiencies in existing data, and that these shortcomings reflected the fragmented structure of a CJA program in which

18. On December 9, 1991, the President signed the Technical Corrections Act of 1991, Pub. L. No. $102-198, \S 9,105$ Stat. 1623, 1626 (1991), which amended the Judicial Improvements Act of 1990 to extend the report's due date to March 31, 1993.

19. In fact, all of the Committee meetings were open and were attended by at least one representative of the federal defenders, as well as, on occasion, a representative of the panel attorneys.

20. See generally COMMITTEE REPORT, supra note 4, at 2271.

21. See id. at 2281.

22. The Spangenberg Group, Review of Provisions for State Indigent Defense Systems (Dec. 31, 1991) (draft paper on file with Review Committee). 
administrative and oversight responsibilities are dispersed among a number of organizational entities. The Committee collected empirical data on threshold matters such as the number of CJA representations, the federal defender-topanel attorney proportion of caseload, budgets, and appropriations. ${ }^{23}$ However, in other areas, such as how frequently the courts reduced panelattorney vouchers or whether there were unreasonable delays in payment, adequate statistics were lacking. Moreover, formal analyses of the quality of services delivered by federal defender organizations and panel attorneys did not exist. $^{24}$

The lack of reliable data affected the Review Committee's approach to the issues before it. Given time and budget constraints, the Committee faced difficult decisions as to the best means of studying various areas and drawing appropriate conclusions. The Committee discussed different means of researching the issues before it, including empirical surveys. Indeed, one of the tasks assigned to the Committee's consultant was to develop methods for surveying CJA attorneys and the judiciary, to see whether various claims could be substantiated.

Ultimately, however, the Committee decided that the cost of such surveys, both in time and money, outweighed the potential benefits. For instance, when the Committee convened in November 1991, it had already received valuable comment from the judiciary and the criminal defense bar. Although statistical data on voucher reductions and processing delays was lacking, complaints on the subject were pervasive among comments from defense attorneys. A common criticism was that the power of the court to reduce vouchers and to withhold approval for significant lengths of time chilled panel attorneys' willingness to accept future appointments. The Committee concluded that this widespread perception of the effects of voucher reductions and payment delays, regardless of the number of actual occurrences, signaled a serious problem in the operation of the CJA. Because there were plausible views that the compensation of CJA counsel could have an impact on the quality of services, the Committee believed the issue required remedial action.

23. Even such basic data as the number of panel attorney appointments, however, which is estimated from the number of vouchers processed for payment during the relevant time period, were found to have questionable reliability. COMMITTEE REPORT, supra note 4, at 2316 endnote 1.

24. See id. at 2286, 2324 endnote hh. The Judicial Conference concurred in the Review Committee's assessment that better statistics and budget information are required:

[A]dditional reliable statistical and financial data are needed to document and guarantee the efficiency and effectiveness of the program in each judicial district of the country.

It would be extremely beneficial, for example, for decision makers to receive more complete and refined data on such matters as the total hours spent by federal defender organization attorneys on cases, time comparisons between federal defender organizations and panel attorneys, the amounts of compensation and expenses claimed by panel attorneys compared to that approved by the courts, the time taken by the courts to process and pay vouchers, and various sorts of information on the quality of representation provided by CJA attorneys.

CONFERENCE REPORT, supra note 6, at 2009. 
In other aspects of the CJA program, however, the foundation to assess current circumstances was inadequate. For example, the Review Committee concluded that further study is needed to determine whether CJA services are provided to persons who do not meet the CJA's financial eligibility requirements, and, if so, whether efforts to seek reimbursement from those persons should be enhanced. ${ }^{25}$ Although the Committee discovered little information on the subject, it felt that the potential savings to the defender services appropriation should be explored, especially in this age of limited fiscal resources. Thus, the Committee recommended that an in-depth, statistically based study of this matter be conducted to identify whether a problem exists. ${ }^{26}$

The Committee was determined not only to hear from a broad spectrum of organizations and individuals, but also to engage them in discussions of the issues. A primary forum for doing so consisted of five regional public hearings held by the Committee across the country. ${ }^{27}$ These hearings provided an invaluable opportunity for all members of the criminal justice community to present their views and debate the issues under study. One of the hearings was televised on the C-SPAN public affairs channel; all were transcribed for the public record.

When the hearings were completed in May 1992, the Review Committee devoted itself to preparing its interim report. As planned, a draft was submitted to the Defender Services Committee in June, and five members of the Review Committee attended a meeting of the Defender Services Committee later that month to discuss the preliminary findings and conclusions. The Review Committee then met in July to consider the comments it had received, and by month's end completed its interim report. Following submission of the interim report to the Judicial Conference in August 1992, the Executive Committee of the Conference granted my request on behalf of the Review Committee to release it for public comment. ${ }^{28}$

In the ensuing weeks, the Review Committee received a number of responses to the interim report from interested parties. ${ }^{29}$ This feedback helped

25. Under the CJA, if the court determines that funds are available for payment from or on behalf of a person furnished representation, it may direct that such funds be paid to the service providers, or to the court for deposit in the Treasury to reimburse the defender services appropriation. 18 U.S.C. $\S 3006 \mathrm{~A}(\mathrm{f})(1988)$.

26. COMMTTEE REPORT, supra note 4, at 2305. The Judicial Conference endorsed this recommendation. CONFERENCE REPORT, supra note 6, at 2009-10.

27. In addition, meetings were held with judges and federal defenders, and officials from Capitol Hill, federal agencies, and the military criminal defense system. Committee members also attended meetings of the American Bar Association, the National Legal Aid and Defender Association, and the National Association of Criminal Defense Lawyers.

28. INTERIM REPORT OF THE COMMITTEE TO REVIEW THE CRIMINAL JUSTICE ACT (1992), reprinted in 51 Crim. L. Rep. (BNA) 2335 (1992) [hereinafter INTERIM REPORT].

29. Unfortunately, the Review Committee was unable to obtain the views of the Judicial Conference, which already had a full agenda for its September 1992 session. The Conference did adopt the following resolution at that session:

[T]o request the Defender Services Committee to undertake a detailed review and analysis of the [interim report]. In order to allow sufficient time to the Judicial 
shape the Committee's agenda in the preparation and submission of the final report to the Judicial Conference in January 1993. For example, criticism was directed at the lack of empirical data in the interim report. Since the interim report was a summary document prepared under severe time constraints, it necessarily could not include particularized substantiation on all of the Committee's preliminary findings. ${ }^{30}$ Accordingly, the Committee continued its data collection efforts over the next few months, and thoroughly annotated its final report with supporting citations from the record of its study.

The Review Committee met in October and December 1992 and January 1993 to complete work on its report. Throughout that period, the Committee maintained contact with the criminal justice community. This enabled the Committee to revise and refine its recommendations in light of the additional comments it received. The Committee also drafted proposed legislation to implement its recommendations, ${ }^{31}$ and the Administrative Office of the U.S. Courts performed cost analyses on them. ${ }^{32}$

\section{$\mathrm{V}$ \\ FINAL REPORT}

The Review Committee's product is embodied in its 212-page report, which was submitted to the Judicial Conference on January 29, 1993. The report describes the historical evolution of appointed counsel in the federal courts and the current status of the CJA program. It recaps the Committee's activities and presents its findings in detail. Based on those findings, the report makes twenty-eight specific recommendations to improve the CJA program. Key areas of attention include: selection, training, evaluation, and compensation of panel attorneys; establishment of new federal defender organizations and personnel practices involving defender organizations; CJA funding; and administrative structure. ${ }^{33}$

The Judicial Conference's Executive Committee once again authorized public release of the report before the Conference's March 1993 session so that

Conference to consider this matter fully so that it may file a timely report with the Congress, on April 1, 1993, ... the Defender Services Committee should report back on or before January 15, 1993.

RePORT OF THE PROCEEDINGS OF THE JUdiCIAL CONFERENCE OF THE UNITED STATES 84 (Sept. 22, 1992).

30. The Committee addressed this point in the interim report, declaring that its findings were "amply supported by the information it has received from hundreds of individuals with experience in the criminal justice system." INTERIM REPORT, supra note 28 , at 2341 n.6.

31. COMMITTEE REPORT, supra note 4, at 2308-15.

32. The AO's Judicial Impact Office is responsible for estimating the cost of proposed legislation. Its analysis of the Review Committee's proposals is discussed in the "Cost Analysis" section of the Committee Report and is appended to the Report. See id. at 2305-06, 2333-45.

33. The Defender Services Committee supported the vast majority of the recommendations proposed by the Review Committee, with the basic disagreement concerning the recommendations for reform in the administrative governance of the program. RESPONSE OF THE COMMITTEE ON DEFENDER SERVICES TO THE INTERIM REPORT OF THE CRIMINAL JUSTICE ACT REVIEW COMMITTEE, reprinted in 52 Crim. L. Rep. (BNA) 2346 (1993). 
all interested parties could have early access to it. The Executive Committee set six recommendations for discussion at the March meeting, including presentations by the chairmen of the Review Committee (myself) and the Defender Services Committee (Judge Gustave Diamond of the Western District of Pennsylvania) on behalf of our respective committees. Following discussion and conference action on those recommendations at the March 16 session, a three-member ad hoc committee of the Conference was appointed to oversee preparation of the Conference's final report to Congress. The final report concurred, in most instances, with the recommendations made by the Review Committee and by the Defender Services Committee, and also made additional recommendations. It followed the Defender Services Committee position in rejecting the Review Committee's recommendations on administrative structure, including the proposal for an independent agency in the judiciary (the Center for Federal Criminal Defense Services) to administer the program nationally. After the Conference voted its approval, the final report was submitted to Congress on March 31, 1993.

The Review Committee was gratified that so many of its proposals were endorsed by the Judicial Conference, not only because of the personal time and energy invested, but, more importantly, because this endorsement portends major improvements to the federal defender program. For example, a number of items relating to the panel-attorney component of the program were adopted, including the need for

eligibility standards for membership on a CJA panel, including development of an equal employment opportunity program;

additional training programs;

support services for panel attorneys in every district;

performance standards and reviews for panel attorneys;

increased compensation for panel attorneys to a level covering reasonable office overhead and fair fees;

required compensation for panel attorney's time spent on necessary and reasonable travel;

authorization for panel attorneys to use paralegals and law students, at reduced hourly rates, to assist in CJA representations;

prompt payment of panel attorneys, experts, and other providers of defense services; and

absent fair compensation levels, indemnification of panel attorneys for civil malpractice and related actions arising from their CJA services. 
Similarly, with respect to federal defender organizations and post-conviction defender organizations, the Conference essentially agreed with all of the Review Committee's recommendations to

require the establishment of a federal defender organization in any district, or combination of districts, where it would be cost effective, where more than a specified number of CJA appointments are made annually, or where it is in the interests of effective representation;

monitor equal employment opportunity in federal defender offices;

develop evaluation procedures to review attorney and staff performance in these organizations;

develop standards for managing federal defender offices;

examine the need for specific standards and procedures regarding the reappointment and removal of federal public defenders;

equalize salaries in federal defender offices with comparable positions in the U.S. Attorneys' offices; and

provide full funding for the post-conviction defender organization program.

Another series of Review Committee recommendations relating to litigation support were also supported by the Judicial Conference:

making counsel available to defendants as early as possible;

developing a pilot program to give certain defendants a limited choice of appointed counsel;

providing discretion for judges in appropriate circumstances to order that funds be provided to CJA-eligible persons for travel to and from court proceedings and related consultations and for subsistence during them;

considering changes in the prosecution's obligation to make discoverable materials available to appointed counsel; and

considering reimbursement of defense fact witnesses by the CJA program rather than the Department of Justice.

Finally, the Judicial Conference strongly favored the Review Committee's call for adequate funding of the CJA program. ${ }^{34}$

34. The Judicial Conference also endorsed two previously mentioned recommendations of the Review Committee: (1) to review the CJA program comprehensively every seven years and (2) to study reimbursement of the CJA by certain defendants. See supra notes 11 and 26 and accompanying text. 
Of course, there were some feelings of disappointment that not all of the Review Committee's recommendations were adopted by the Conference. ${ }^{35}$ Reasonable persons disagree as to the merits and demerits of the judiciary's current role in the administration of the CJA program. The Review Committee preferred a system with less judicial involvement. This does not detract, however, from the overall sense of accomplishment in the review process and the promise of an improved appointed-counsel system in the federal courts. Indeed, there is already concrete evidence that the CJA study is bearing fruit in program operations. For example, the United States District Court for the District of Massachusetts revised its CJA plan ${ }^{36}$ to conform with many of the Review Committee's recommendations. ${ }^{37}$ There has been a noticeable increase in the number of districts that have established federal defender organizations. New guidelines and reporting procedures have been approved by the Judicial Conference to expedite judges' review of vouchers for fees and expenses of panel attorneys, experts, investigators, and other providers of defense services. ${ }^{38}$ Further steps from the judiciary and the defender services community, as well as from Congress, are expected with respect to many of the recommendations generated by the review process.

Even beyond the more immediate proposals for enhancing the appointedcounsel system, perhaps the greatest dividend from the CJA study is that it has spurred public debate regarding the CJA program's goals, strengths, and weaknesses. A sense of momentum has been achieved, but it is critical to continue the analytical process in order to maintain progress in the provision of quality criminal defense services for the poor.

35. See, e.g., Judiciary to Congress on CJA: Nothing's Broke Cash Won't Fix, 7 BNA CRIM. PRAC. MANUAL 171 (1993).

36. The CJA requires that each district court, with the approval of the judicial council of the circuit, have a formal plan for furnishing CJA representation to eligible persons. 18 U.S.C. $\$ 3006 \mathrm{~A}(\mathrm{a})(1988)$.

37. The report accompanying the revisions to the Massachusetts plan expressly follows the Review Committee's positions on several issues. See Report of the Committee to Evaluate the Performance of the Criminal Justice Act Plan for the District of Massachusetts, MASS. LAW. WKLY., June 21, 1993 (special section).

The new Massachusetts plan establishes a CJA Board, consisting of 10 private attorneys and the federal public defender, who serves ex officio, to assist the court in managing the district CJA program. One of the Board's responsibilities is to participate in the selection of attorneys to serve on the CJA panel. The plan institutes qualification standards for panel attorneys, equal employment opportunity policies, limits on the size of the panel, a formal procedure for reviewing and revising the panel, a case assignment system, regular training, and a mentoring program to provide attorneys with added training or experience to be eligible for service on the panel. Also, the new CJA Board is authorized to create a CJA Advisory Committee of up to 25 attorneys, experienced in federal district court practice, who would be available for consultation, without compensation, by panel attorneys.

38. The Guidelines for the Administration of the Criminal Justice Act were revised in June 1993 to state that "[a]bsent extraordinary circumstances, judges should act upon [claims for compensation for CJA services] within 30 days of submission." Guidelines for the Administration of the Criminal Justice Act, 19 2.21, 3.07, 6.02(D), 6.03(E), reprinted in 7 GUIDE TO JUDICIARY POLICIES AND PROCEDURES: APPOINTMENT OF COUNSEL IN CRIMINAL CASES. 


\section{VI \\ CONCLUSION}

As the federal criminal justice system evolves, the CJA program must adapt to ever-changing conditions. Altering the status quo, however, is never easy. Reflecting on my personal experience on the Review Committee, and without advocating any particular proposal for CJA reform, my basic observation is consistent with the oft-repeated truisms that change is a dynamic process and that those who embark on the journey will meet resistance.

Some resistance is based on valid premises: "If it ain't broke, don't fix it," and "change for the sake of change can be destructive." But the wisdom that lies at the heart of these aphorisms must be balanced against a recognition that the movement to provide counsel to all who are entitled is a relatively young phenomenon in the administration of justice. The system for compensating counsel for representing impecunious defendants, as instituted by the passage of the CJA, is still an innovation. Today, the vast majority of federal defendants require CJA representation. Annual appointments in 80,000 CJA matters, an increase of sixty percent since $1983,{ }^{39}$ signal that a major revolution in the administration of criminal justice is in progress. By sheer number, CJA counsel are setting the standards for the defense of federal defendants. Thus, the CJA program has become the standard of representation in the federal courts.

Accordingly, we must ensure that the best framework is in place for optimal operation of the appointed counsel program, especially in these fiscally austere times. As the Review Committee found, the development of this framework is an ambitious process. We must be prepared to move forward and to recognize and take advantage of the possibilities for improvement. Increased awareness from forums such as this symposium substantially advance this endeavor.

39. Compare COMMITEE REPORT, supra note 4, at 2278, with REPORT OF THE PROCEEDINGS OF THE JUDICIAL CONFERENCE OF THE UNITED STATES 32 (Mar. 16-17, 1983). 
